\title{
What's There to Mourn? Decolonial Reflections on (the End of) Liberal Humanitarianism
}

\author{
Olivia Umurerwa Rutazibwa \\ Senior Lecturer in European and International (Development) Studies, University of Portsmouth; olivia.rutazibwa@port.ac.uk
}

\begin{abstract}
This paper questions the extent to which the (arguable) end of the liberal humanitarian order is something to be mourned. Suggesting that current laments for the decline of humanitarianism reflect a Eurocentric worldview, it calls for a fundamental revision of the assumptions informing humanitarian scholarship. Decoloniality and anticolonialism should be taken seriously so as to not reproduce the same by a different name after the end of the liberal order.
\end{abstract}

Keywords: aid, (de)coloniality, development, epistemology, Eurocentrism, liberal humanitarianism

All over the globe, fascism, racism and xenophobic nationalism are resurfacing in what we once thought of as 'respectable' democracies. Following a particularly bleak weekend at the end of October 2018 (the election of Jair Bolsonaro in Brazil, reports of worsening famine in Yemen, Israeli bombardment of Gaza and the murder of eleven worshippers at a refugee-harbouring synagogue in Pittsburgh), my colleague Dr Sara Salem of the London School of Economics tweeted: 'It's difficult watching political scientists scrambling to understand what's happening around the world today as if there haven't been people... theorising racism, nationalism, empire and gender for a century and warning of exactly what we see now.'

Moulded by Eurocentric knowledge systems, most of us react to such developments with utter shock. We - an imagined citizenry of respectable democracies - are horrified and appalled at how far we have been dragged from our liberal, more-or-less progressive self-image. And we are invited to consider whether we might be witnessing the end of the liberal humanitarian order.

Eurocentrism has taught us to see the potential end of an era in every relative change in Western power. Thinking about the role of humanitarianism today requires that we don't reproduce or unwittingly celebrate Western-led order by mourning the end of a history that never actually existed. Given past and present non-Western experiences of liberal order, we might ask: what's there to mourn?
My personal experiences of research and knowledge production regarding humanitarianism have reinforced in me an anti-colonial ethos - an intellectual opposition to coloniality, even in the most 'benign' of research and policy areas, like international aid and humanitarianism. Coloniality can be understood as the perpetuation of colonial systems and technologies of domination into the present. As discussed by scholars such as Quijano, Grosfoguel, Dussel and Ndlovu-Gatsheni, the concept of decoloniality encourages systemic and historical analysis of the organised (re)production of injustice and mass human suffering.

Formal colonialism (which arguably existed from 1492 to the 1960s) and transatlantic enslavement are but two means through which Europeans made themselves the protagonists of global history. Europeans then rewrote their history, erasing the mass human suffering they had caused, promoting instead tales of white European innocence (Wekker, 2016), superiority and exceptionalism. In its destruction of life, coloniality might be considered anti-humanitarian, and yet it is characteristic of the liberal humanitarianism whose end we now (prematurely) are invited to mourn.

For over two decades, I have been struggling to make sense of humanitarian interventions. The topic was thrust upon me by events in Rwanda in 1994. As a teenage, second-generation Rwandan immigrant in Belgium, I was more personally affected than fellow classmates by the hypocrisy of the international
MANCHESTER 1824

Manchester University Press 
community: the preaching of respect for human rights, followed by their omission during one hundred days of mass murder before the eyes of the world. It felt like there was more to the story than 'good intentions versus regrettable outcomes'.

Ever since, I have worried about the content and purpose of (Western) humanitarian research agendas. I became cognisant of the limited efforts to understand how good intentions coexist with a system of international aid and intervention that seems harmful not for the few but for the many. The silence of too many researchers simultaneously masks and normalises the harmful consequences of the aid system.

The scholarship and advice I was exposed to as my early academic career developed prompted me to explore the contradictory logic of international aid empirically: I set out to make a database of the EU's 'ethical' behaviour (sanctions, funding, declarations and military and humanitarian interventions, in relation to human rights and democracy) between 1999 and 2007 towards the countries of sub-Saharan Africa. I did not find any patterns that could fully explain the EU's action or inaction: not a country's size, nor its former colonial masters, its natural resources, the Member State presiding over the EU, nor even the African target country's human rights or humanitarian situation. After a stint at the European Commission's Directorate General of External Affairs, I also came to reject simplistic accounts about the absence of good intentions of the people devising and implementing aid policies.

I realised that I - and mainstream IR with me - had operated on an assumption that external involvement in the affairs of the 'developing world', if well intentioned and effective, was desirable, indispensable even. Letting go of this assumption opens up a world of possibilities for the study of intervention. Doing so, I reconsidered the conventional narrative that attributes the genocide against the Tutsi in Rwanda to non-intervention, and came to see that the (post)colonial run-up to genocide was a story of too much intervention, even in the name of democracy.

During my doctoral research, I rediscovered the case of Somaliland. A self-declared independent republic in the north-western corner of Somalia, Somaliland had declined US and UN interventions at the beginning of the 1990s, apart from specific assistance (the clean-up of landmines, for example). Instead, it took care of its peace-building process internally and with its diaspora. Over the years, even though the international community had found its way to the capital, Hargeisa, Somaliland had arguably become the most stable democracy in the region, even as it awaited international recognition of its independence. It seemed to me, therefore, that the most salient question was not how intervention could be more effective and efficient, but whether it was necessary in the first place. Was Western presence itself constitutive of the problems facing 'host' countries?

In her recent book Decolonising Intervention: International Statebuilding in Mozambique (2017), Meera Sabaratnam offers a compelling feminist decolonial analysis of international statebuilding in the postcolony. She foregrounds in-country critiques of foreign presence via the concept of protagonismo; and she reflects on disposability (of the 'beneficiaries'), dependency (on the interveners) and entitlement (of the interveners) as constitutive of interventions and not just technical glitches. If only I had had access to this work when I began my inquiry into humanitarianism.

I now include Sabaratnam's book as a core text for final-year undergraduate students reading International Development Studies and International Relations at the University of Portsmouth. My module on 'Rethinking Aid and Development' explores the implications of decolonial engagement with ideas and practices of international solidarity. Students have said: 'We should be assigned readings like this from year one.' So I ask the question here: 'What if we were to start our humanitarian conversation with Sabaratnam?'

Of course, other works have questioned the value of international intervention. But it is necessary to reflect on the consequence of their marginality in the canon. Privileged research agendas shape academic career paths; and, increasingly, careers in 'the real world' shape academic disciplines. In this context, the marginalisation of critical decolonial perspectives in research and in practice becomes mutually reinforcing.

A decolonial approach to humanitarianism challenges Eurocentric analyses, foregrounding the experiences and knowledges of the intended targets of humanitarian aid. It poses questions not so much about the political will, operational implementation and technical capabilities of humanitarians as about the perpetuation of colonial power relations in seemingly benevolent activities.

Decoloniality asks: where do we start the story? Who has the microphone and who usually doesn't? What do we consider expertise? What are the implications of Eurocentric bias in knowledge production? Do our practices and knowledge systems contribute to the struggle against colonial power relations?

As we reflect on the potential end of liberal order, decoloniality questions what we mourn. With humanitarianism itself being redefined, decolonial perspectives can contribute to an understanding of the relevance of the good intentions of humanitarians to the aspirations of their intended 'beneficiaries'. They can provide an antidote to the 'colonial amnesia' of liberal humanitarians and, therefore, provide a basis for the critical interrogation of, and contribution to, humanitarian endeavours in the service of life and dignity and not 
merely of survival. They can challenge not only the ideological character of a given order but also the power relations essential to it - something that the 'local turn' in humanitarian thinking has not done, despite discussion of 'shifting power'.

Without these perspectives informing research and policy agendas, whatever comes next is unlikely to be very different for those previously robbed of power and voice. Mourning the end of an order responsible for mass human suffering, while that suffering continues, then becomes an indulgent act of self-delusion.

\section{Bibliography}

Dussel, E. (1993), 'Eurocentrism and Modernity (Introduction to the Frankfurt Lectures)', Boundary 2, 20:3, 65-76.

Dussel, E. (2008), Twenty Theses on Politics (Durham, NC: Duke University Press).

Grosfoguel, R. and Cervantes-Rodriguez, A. M. (2002), 'Introduction: Unthinking Twentieth-century Eurocentric Mythologies: Universal
Knowledge, Decolonization, and Developmentalism', in Grosfoguel, R. and Cervantes-Rodriguez, A. M. (eds), The Modern/Colonial/ Capitalist World-System in the Twentieth Century: Global Processes, Antisystemic Movements, and the Geopolitics of Knowledge (Westport, CT: Praeger Publishers), pp. xi-xxix.

Ndlovu-Gatsheni, S. J. (2012), 'Coloniality of Power in Development Studies and the Impact of Global Imperial Designs on Africa', Australasian Review of African Studies, 33:2, 48-73.

Ndlovu-Gatsheni, S. J. (2018), 'Racism and Blackism on a World Scale', in Rutazibwa, O. U. and Shilliam, R. (eds), Routledge Handbook of Postcolonial Politics (London: Routledge), pp. 72-86.

Quijano, A. (2000), 'Coloniality of Power and Eurocentrism in Latin America', International Sociology, 15:2, 215-32.

Quijano, A. (2007), 'Coloniality and Modernity/Rationality', Cultural Studies, 21:2-3, 168-78.

Rutazibwa, O. U. (2018), 'On Babies and Bathwater: Decolonizing International Development Studies', in de Jong, S., Icaza, R. and Rutazibwa, O. U. (eds), Decolonization and Feminisms in Global Teaching and Learning (London: Routledge), pp. 192-214.

Sabaratnam, M. (2017), Decolonising Intervention: International Statebuilding in Mozambique (London: Rowman \& Littlefield International).

Wekker, G. (2016), White Innocence: Paradoxes of Colonialism and Race (Durham, NC: Duke University Press). 